\title{
PENGARUH OPINI AUDIT, DEBT TO EQUTY RATIO (DER), RETURN ON ASSET (ROA),CURRENT RATIO (CR) DAN UKURAN PERUSAHAAN TERHADAP KETEPATAN WAKTU PENYAMPAIAN LAPORAN KEUANGAN DIPERUSAHAAN JASA SEKTOR PERDAGANGAN, DAN INVESTASI YANG TERDAFTAR DI BURSA EFEK INDONESIA TAHUN 2016-2017
}

\author{
NATAL KRISMAN LAHAGU \\ EVELIN R.R. SILALAHI \\ ESLI SILALAHI
}

Program Studi Akuntansi Universitas Katolik Santo Thomas Medan natalkrismanlahagu@yahoo.com; evelinsilalahi37@gmail.com; esli2silalahi@gmail.com

\begin{abstract}
ABSTRAK
Penelitian ini bertujuan untuk mengetahui dan memberikan bukti secara empiris, Apakah Opini Audit, debt to equity ratio (DER), Return on Asset (ROA), Current ratio $(C R)$ dan Ukuran Perusahaanberpengaruh terhadap ketepatan waktu penyampaian laporan keuangan diperusahaan jasa sektor perdagangan jasa dan investasi yang terdaftar di Bursa Efek Indonesia Tahun 2016-2017. Teknik pengambilan sampel digunakan adalah purposive sampling dengan jumlah sampel 74 perusahaan. Data diperoleh dari Bursa Efek Indonesia dengan situs www.idx.co.id tahun 2016-2017. Teknik analisis data yang digunakan adalah regresi logistik dengan tingkat signifikan 5\%. Hasil uji menunjukkan bahwa Opini Auditor dan Ukuran Perusahaan berpengaruh positif dan signifikan terhadap ketepatan waktu penyampaian laporan keuangan, Current ratio $(C R)$ berpengaruh negatif dan signifikan terhadap ketepatan waktu penyampaian laporan keuangan,Debt To Equity Ratio (DER)berpengaruh negatif dan tidak signifikan terhadap ketepatan waktu penyampaian laporan keuangan dan Return on Asset (ROA) berpengaruh Positif dan tidak signifikan terhadap ketepatan waktu penyampaian laporan keuangan.
\end{abstract}

Kata Kunci: Tepat waktu, Opini Audit, Debt To Equity Ratio (DER), Return On Asset (ROA), Current ratio (CR) dan Ukuran Perusahaan

\section{PENDAHULUAN}

Pasar modal mempunyai peranan yang penting bagi perekonomian disuatu Negara. Bisnis investasi ini akan menjadi sedemikian kompleks dengan tingkat persaingan yang semakin ketat. Terutama dalam upaya penyediaan dan perolehan informasi dalam setiap pengambilan keputusan. Salah satu sumber informasi penting dalam bisnis investasi di pasar modal adalah laporan keuangan yang disediakan setiap perusahaan yang Go Publik. Pelaporan keuangan merupakan sarana bagi perusahaan untuk menyampaikan berbagai informasi dan pengukuran secara ekonomi 
mengenai sumber daya yang dimiliki serta kinerjanya kepada berbagai pihak yang memiliki kepentingan atas informasi tersebut.

Investor sebagai pemegang saham atau pemilik perusahaan dari pihak luar memerlukan laporan keuangan untuk mengetahui tingkat kembalian (rate of return) atas investasi dan membantu untuk memutuskan tindakan mereka baik untuk membeli, menahan, atau menjual sahamsaham perusahaan. Tepat waktu dapat diartikan bahwa informasi harus disampaikan secepat mungkin agar dapat digunakan sebagai dasar dalam pengambilan keputusan ekonomi dan untuk menghindari tertundanya pengambilan keputusan tersebut.

Ketepatan waktu penyampaian laporan keuangan juga dapat diartikan sebagai salah satu dasar pengambilan keputusan untuk membeli atau menjual kepemilikan yang dimiliki oleh investor sebagai dasar penentuan tindakan pada masa yang akan datang. Keterlamabatan informasi akan menimbulkan reaksi negatif dari pelaku pasar modal. Informasi yang disajikan tidak tepat waktu akan mempersulit para pemakainya memprediksi atau menganalisisi perusahaan-perusahaan tersebut.

Penyampaian laporan keuangan bagi perusahaan publik diatur dalam peraturan paling baru yang dikeluarkan oleh OJK (otorisasi jasa keuangan), yaitu

peraturan No 29 /POJK.04/2016 tentang penyampaian laporan tahunan emiten atau perusahaan. Peraturan tersebut menyebutkan bahwa perusahaan publik yang

pernyataan pendaftarannya telah menjadi efektif wajib menyampaikan laporan tahunan kepada OJK (otorisasi jasa keuangan) paling lama akhir bulan ke 4 setelah tahun buku berakhir (OJK, 2016). Keterlambatan pelaporan keuangan masih terjadi dapat dihitung tanggal publikasinya ke BEI, keterlambatan pelaporan keuangan ini dapat mempengaruhi informasi yang dipublikasikan, sehingga akan berpengaruh terhadap ketidak pastian keputusan berdasarkan informasi yang tidak relevan lagi. Keterlambatan penyampaian laporan keuangan diatur juga oleh PT. Bursa Efek Indonesia sampai 30 hari akan diberi sanksi berupa peringatan tertulis I. Bursa memberikan peringatann tertulis II dan denda Rp. 50.000 .000 ( seratus lima puluh juta ) dan suspense efek perusahaan tercatat dibursa jika keterlambatan lebih dari 90 hari.

IAI (2018:8) menyatakan bahwa tepat waktu merupakan salah satu kendala informasi yang relevan dan andal, dan jika terdapat penundaan yang tidak semestinya dalam pelaporan, maka informasi yang dihasilkan 
akan kehilangan relevansinya. Menyampaikan dikatakan tepat waktu apabila laporan keuangan disampaikan paling lambat pada akhir bulan keempat atau 120 hari setelah tanggal laporan keuangan tahunan dan dikatakan tidak tepat waktu apabila laporan keuangan disampaikan lebih dari 120 hari setelah tanggal pelaporan keuangan. Manajemen mungkin perlu menyeimbangkan manfaat relative antara pelaporan tepat waktu dan ketentuan informasi andal.

Untuk menyediakan informasi tepat waktu, seringkali perlu melaporkan sebelum seluruh aspek transaksi atau peristiwa lainnya diketahui, sehingga mengurangi keandalan informasi. Sebaliknya jika pelaporan ditunda sampai seluruh aspek diketahui, informasi yang dihasilkan mungkin sangat andal tetapi kurang bermanfaat bagi pengambil keputusan. Dalam usaha mencapai keseimbangan antara relevansi dan keandalan, kebutuhan pengambil keputusan merupakan pertimbangan yang menentukan.

Penelitian tentang ketepatan waktu penyampaian laporan keuangan telah banyak dilakukan, namun memiliki hasil yang berbeda-beda diantaranya adalah sebagagai berikut:

Penelitian R. Ait Novatiant dan Nadia Putri A (2016) tentang Pengaruh Leverage (CR), Ukuran Perusahaan, Opini Auditor, dan Kompleksitas Operasi Perusahaan terhadap ketepatan waktu penyampaian laporan keuangan perusahaan. Obyek penelitian terdiri dari 73 perusahaan manufaktur yang terdaftar di BEI , menyimpulkan bahwa Leverage (CR), Ukuran Perusahaan, Opini Auditor, dan Komplasitas Operasi Perusahaan secara parsial dan secara simultan berpengaruh signifikan terhadap ketepatan waktu penyampaian laporan keuangan perusahaan.

Penelitian Desi uli silalahi (2016) tentang pengaruh DER, ROA dan Ukuran perusahaan terhadap ketepatan waktu penyampain laporan keuangan perusahan Real estate dan Property yang terdaftar di BEI tahun 2012-2014 menyimpulkan bahwa DER dan ROA berpengaruh negatif dan tidak segnifikan terhadap ketepatan waktu penyampaian laporan keuangan sedangkan Ukuran Perusahaan berpengaruh positif dan signifikan terhadap ketepatan waktu penyampaian laporan keuangan.

Penelitian Nafilah ulfa Anggreni (2018) faktor faktor yang mempengaruhi ketetpatan waktu pelaporan keuangan pada perusahaan tambang yang tereindeks di ISSI tahun 2016-2017 yang mengunakan variable independen Struktur Kepemilikan, Leverage, Profitabiltas, Reputasi Audit dan Likuiditas menyimpulkan bahwa Struktur 
Kepemilikan, Leverage,Profitabiltas, Reputasi Audit dan Likuiditas tidak berpengaruh terhadap ketepatan waktu pelaporan

Dari beberapa penelitian sebelumnya penulis ingin melakukan replikasi dariPenelitian Nafilah Ulfa Anggraini (2018) tentang faktor faktor yang mempengaruhi ketepatan waktu pelaporan keuangan pada perusahaan Tambang yang tereindeks di ISSI tahun 2016-2017 yang mengunakan variable independen Struktur Kepemilikan, Leverage, Profitabiltas, Reputasi Audit dan Likuiditas.

Sedangkan yang membedakan dengan penelitian sebelumnya dalam penelitian ini adalah penulis menggunakan sampel perusahaan jasa sektor perdagangan, jasa dan investasi, namun dalam penelitian ini struktur kepemilikan diganti menjadi opini audit dan reputasi audit diganti manjadi ukuran perusahaan.

Meskipun penelitian ketepatan waktu penyampaian laporan keuangan telah banyak dilakukan, namun memiliki hasil yang berbeda-beda yang menimbulkan penelitian lanjutan untuk membuktikan bagaimana pengaruh Opini Audit, DER, ROA, CR dan Ukuran Perusahaan terhadap ketepatan waktu penyampaian laporan keuangan.

Berdasarkan latar belakang di atas, maka penulis merumuskan masalah yaitu“Apakah Opini Audit, Debt To Equity Ratio (DER), Return Of Asser (ROA), Current Ratio (CR) dan Ukuran perusahaan berpengaruh terhadap ketepatan waktu penyampaian laporan keuanganpada perusahaan jasa sektor perdagangan, dan investasi yang terdaftar di Bursa Efek Indonesia 2016-2017?"

\section{TINJAUAN PUSTAKA DAN HIPOTESIS}

\section{Laporan Keuangan}

Dalam IAI (2018:9) menyatakan bahwa Laporan Keuangan menggambarkan dampak keuangan dari transaksi dan peristiwa lain yang diklasifikasikan dalam beberapa kelompok besar menurut karakteristik ekonominya Laporan Keuangan bertujuan untuk menyediakan informasi yang menyangkut posisi keuangan, kinerja, serta perubahan posisi keuangan suatu perusahaan yang bermanfaat bagi sejumlah besar pengguna dalam pengambilan keputusan ekonomi.

Sedangkan laporan keuangan menurut Kasmir (2012:7) merupakan Laporan yang menunjukkan kondisi keuangan perusahaan pada saat ini atau dalam suatu periode tertentu. Maksud dari laporan keuangan yang menunjukkan kondisi perusahaan saat ini adalah merupakan kondisi keuangan perusahaan terkini. Kondisi perusahaan terkini adalah keadaan 
keuangan perusahaan pada tanggal tertentu (untuk neraca) dan periode tertentu (untuk laporan laba rugi).

\section{Peraturan Penyampaian Laporan Keuangan di Indonesia}

Penyampaian laporan keuangan ini merupakan hal yang wajib dilakukan oleh perusahaan sebagaimana disebutkan dalam Undang-undang (UU) No. 8 Tahun 1995 tentang Pasar Modal yang menyatakan secara jelas bahwa perusahaan publik wajib menyampaikan laporan berkala dan laporan insidental lainnyakepada Bapepam. Bapepam menyatakan bahwa setiap perusahaan yang go publicdiwajibkan untuk menyampaikan laporan keuangan yang disusun sesuai dengan

Standar Akuntansi Keuangan dan telah diaudit tepat waktu. Terdapat beberapa peraturan yang dikeluarkan oleh Bapepam (Badan Pengawas Pasar Modal) mengenai ketepatan waktu penyampaian laporan keuangan diantaranya sebagai berikut:

1. Peraturan Bapepam Nomor VIII.G.2 Lampiran Keputusan Ketua Badan

2. Peraturan Bapepam Nomor X.K.2 Lampiran Keputusan Ketua Bapepam Nomor: KEP-36/PM/2003 Menjelaskan kewajiban penyampaian laporan keuangan tahunan .

3. Peraturan Bapepam Nomor X.K.6 Lampiran Keputusan Ketua Badan Pengawas Pasar Modal Nomor: KEP-134/BL/2006 Menjelaskan Kewajiban penyampaian laporan tahunan.

4. Peraturan Bapepam Nomor X.K.2 Lampiran Keputusan Ketua Badan Pengawas Pasar Modal Nomor: KEP-346/BL/2011

5. Peraturan Bapepam Nomor X.K.6 Lampiran Keputusan Ketua Bapepam Nomor: KEP-431/BL/2012 Menjelaskan kewajiban penyampaian laporan tahunan.

6. Peraturan Otoritas Jasa Keuangan Nomor: 29/PJOK.04/2016 Menjelaskan penyampaian laporan tahunan.

Selain dari sanksi administrasi tersebut diatas, Bursa Efek Indonesia juga menerbitkan Keputusan Direksi PT. Bursa Efek Jakarta Nomor: 307/BEJ/07-2004 Peraturan I-H tentang sanksi atas Keterlambatan Penyampaian Laporan Keuangan Keterangan Hari Kalender Sanksi Peringatan Tertulis I 1-30 Hari - Peringatan Tertulis II 31-60 Hari Rp. 50.000.000,- Peringatan Tertulis III 61-90 Hari Rp. 150.000.000,Tidak melakukan ketiga peringatan sebelumnya Pemberhentian sementara (Suspen) 


\section{Ketepatan Waktu (Timeliness)}

Menurut IAI (2018:3) bahwa tujuan laporan keuangan adalah menyediakan informasi yang menyangkut posisi keuangan, kinerja, serta perubahan posisi keuangan suatu perusahaan yang bermanfaat bagi sejumlah besar pengguna dalam pengambilan keputusan ekonomi.Informasi yang relevan akan bermanfaat bagi para pemakai apabila tersedia tepat waktu sebelum pemakai kehilangan kesempatan atau kemampuan untuk mempengaruhi keputusan yang akan diambil. Tepat waktu diartikan bahwa informasi harus disampaikan sedini mungkin untuk dapat digunakan sebagai dasar untuk membantu dalam pengambilan keputusan-keputusan ekonomi dan untuk menghindari tertundanya pengambilan keputusan tersebut. Ketepatan waktu tidak menjamin relevansi, tetapi relevansi informasi tidak dimungkinkan tanpa ketepatan waktu. Informasi mengenai kondisi dan posisi perusahaan harus secara cepat dan tepat waktu sampai ke pemakai laporan keuangan, IAI (2018:8).

\section{Opini Audit}

Menurut Mulyadi (2014: 19) Opini audit merupakan opini yang diberikan auditor tentang kewajaran penyajian laporan keuangan perusahaan tempat auditor melakukan audit.. Pemberian opini audit terhadap laporan keuangan menjadi keandalan bagi laporan keuangan perusahaan. Sesuai dengan persyaratan Bapepam bahwa dalam penyampaian laporan keuangan harus disertai dengan opini audit. Perusahan yang cenderung mendapat opini Wajar Tanpa Pengecualian dari auditor untuk laporan keuangannya cenderung akan tepat waktu dalam menyampaikan laporan keuangannya karena pendapat wajar tanpa pengecualian merupakan berita baik dari auditor.

Menurut Mulyadi (2002:416) dalam menyatakan bahwa ada 5 tipe pendapat (Opini) yang akan dinyatakan atas laporan keuangan auditan :

1. Pendapat Wajar Tanpa Pengecualian (WTP) auditor

2. Pendapat Wajar Tanpa Pengecualian Dengan Bahasa Penjelas Yang Ditambahkan Dalam Laporan Audit Bentuk Baku (WTPDBP

3. Pendapat Wajar Dengan Pengecualian (WDP)

4. Pendapat Tidak Wajar (TW).

5. Penyertaan Tidak Memberikan Pendapat (TMP),

Opini audit dihitung dengan variable dummy, dimana setiap perusahaan yang mendapatkan opini Wajar Tanpa Pengecualian (WTP) diberikan skor 1 (Good news) dan perusahaan yang mendapatkan opini audit selain Wajar Tanpa Pengecualian akan diberi skor 0 (Bad news) 


\section{Debt To Eqity Ratio (DER)}

Menurut Kasmir (2012: 157) Debt to Equity Ratio, merupakan rasio yang digunakan untuk menilai hutang dengan ekuitas. Untuk mencari rasio ini dengan cara membandingkan antara seluruh hutang, termasuk utang lancar dengan seluruh ekuitas. Rasio ini berguna untuk mengetahui jumlah dana yang disediakan peminjam (kreditor) dengan pemilik perusahaan. Dengan kata lain rasio ini untuk mengetahui setiap rupiah modal sendiri yang dijadikan untuk jaminan utang.Rasio ini diukur dengan rumus sebagai berikut:

$$
D E R=\frac{\text { Total hutang }}{\text { Ekuitas }} \times 100 \%
$$

\section{Return On Asset (ROA)}

Menurut Hery (2016:196) Return on asset (ROA) merupakan rasio yang menunjukkan seberapa besar kontribusi asset dalam menciptakan laba bersih.. ROA juga merupakan suatu ukuran tentang efektivitas manajemen dalam mengelola asetnya. Rasio ini diukur dengan rumus sebagai berikut:

$$
\text { ReturnOnAsset }=\frac{\text { Laba Bersih }}{\text { Total Aktiva }} \times 100 \%
$$

\section{Current Ratio (CR)}

Menurut Kasmir (2011:134) Current Ratio (Rasio Lancar) merupakan rasio untuk mengukur kemampuan perusahaan dalam membayar kewajiban jangka pendek atau utang yang segera jatuh tempo pada saat ditagih secara keseluruhan. Dengan kata lain, seberapa banyak aktiva lancer yang bersedia untuk menutupi kewajiban jangka pendek yang segera jatuh tempo. Rasio lancer dapat dikatakan sebagai bentuk untuk mengukur tingkat keamanan (margin of safety) suatu perusahaan.

Rasio ini diukur dengan rumus sebagai berikut:

\section{Ukuran Perusahaan}

$$
\text { Rasio Lancar }=\frac{\text { aktiva lancar }}{\text { Kewajiban Lancar }} x 100
$$

Menurut Brigham \& Houston (2010:4) Ukuran perusahaan merupakan ukuran besar kecilnya sebuah perusahaan yang ditunjukan atau dinilai oleh total asset, total penjualan, jumlah laba, beban pajak dan lainlain. Jadi ukuran perusahaan juga dapat diartikan sebagai keseluruhan kekayaan yang dimiliki oleh perusahaan baik dalam bentuk aktiva lancar 
maupun aktiva tetap. Ukuran perusahaan bisa diukur dengan menggunakan total aktiva, penjualan, atau modal dari perusahaan tersebut. Salah satu tolak ukur yang menunjukkan besar kecilnya perusahaan adalah ukuran aktiva dari perusahaan tersebut.

Dimana dalam penelitian ini ukuran perusahaan diukur dengan rumus : Size $=$ Ln Total Asset

\section{PengaruhOpini Auditor dan Ketepatan Waktu Penyampaian Laporan Keuangan}

Menurut Mulyadi (2014: 19) pengertian opini audit yaitu Opini audit merupakan opini yang diberikan auditor tentang kewajaran penyajian laporan keuangan perusahaan tempat auditor melakukan audit". Pemberian opini audit terhadap laporan keuangan menjadi keandalan bagi laporan keuangan perusahaan. Sesuai dengan persyaratan OJK bahwa dalam penyampaian laporan keuangan harus disertai dengan opini audit. Perusahan yang mendapat opini Wajar Tanpa Pengecualian dari auditor untuk laporan keuangannya cenderung akan tepat waktu dalam menyampaikan laporan keuangannya karena pendapat wajar tanpa pengecualian merupakan berita baik dari auditor. Auditor dalam memberikan opini sudah didasarkan pada keyakinan profesionalnya. Tujuan utama audit atas laporan keuangan adalah untuk menyatakan pendapat apakah laporan keuangan klien disajikan secara wajar, dalam semua hal yang material, sesuai dengan prinsip akuntansi berterima umum di Indonesia (Mulyadi, 2002:73). Opini auditor digunakan untuk menyatakan pendapat atas laporan keuangan yang telah diaudit.

Agoes Sukirsno (2013:31) menyebutkanbahwa opini auditor Setiap perusahaan tentunya ingin mendapatkan unqualified opinion atas laporan keuangannya karena opini ini merupakan good news perusahaan. Sedangkan selain unqualified opinion adalah opini yang sebisa mungkin dihindari perusahaan, karena hal ini merupakan bad news perusahaan. Perusahaan yang mendapat unqualified opinion cenderung lebih cepat menyampaikan laporan keuangannya daripada perusahaan yang menerima qualified opini.

\section{Pengaruh DER Terhadap Ketepatan Waktu Pelaporan Keuangan}

Menurut Kasmir (2011:157) Debt To Equity Ratio merupakan rasio yang digunakan untuk menilai utang dengan ekuitas. Ratio ini berguna untuk mengetahui jumlah dana yang disediakan peminjam (kreditor) dengan pemilik perusahaan. Dengan kata lain ratio ini berfungsi untuk 
mengetahui setiap rupiah modal yang dijadikan untuk jaminan utang. Semakin tinggi Debt To Equity Ratio maka berarti semakin kecil jumlah modal pemilik yang dapat dijadikan sebagai jaminan utang .

Selanjutnya Sofyan Syafri Harahap (2008:303) menjelaskan definisi debt to equity sebagai berikut: "Rasio-rasio ini menggambarkan sampai sejauh mana modal pemilik dapat menutupi utang-utang kepada pihak luar. Semakin kecil rasio ini semakin baik dan laporan keuangan tersebut mengandung berita baik dari perusahaan yang mempunyai berita baik akan cendrung menyampaikan laporan keuangannya tepat waktu. Rasio ini juga disebut dengan rasio leverage".

Irfan Haris Setiawan (2014) berpendapat bahwa tingginya rasio DER (Debt to Equity Ratio) mencerminkan tingginya resiko perusahaan. Tingginya resiko ini menunjukan adanya kemungkinan bahwa perusahaan tersebut tidak bisa melunasi kewajiban atau hutangnya baik berupa pokok ataupun bunganya. Kesulitan keuangan ini merupakan berita buruk dimata masyarakat maka dari itu pihak manajemen akan cenderung untuk menunda penyampaian laporan keuangan yang berisi berita buruk.

\section{Pengaruh ROA Terhadap Ketepatan Waktu Penyampaian Laporan Keuangan}

Menurut Herry (2016:196) Return on asset (ROA) merupakan rasio yang menunjukkan seberapa besar kontribusi asset dalam menciptakan laba bersih. Atau ROA juga sering disebut rasio profitabilitas yang digunakan untuk mengukur efektifitas perusahaan didalam menghasilkan keuntungan dengan memanfatkan aktiva yang dimilikinya. Dengan kata lain, rasio ini digunakan untuk mengukur seberapa besar jumlah laba bersih yang akan dihasilkan dari setiap rupiah dana yang tertanam dalam total asset. Semakin tinggi hasil pengembalian atas asset berarti semakin tinggi pula jumlah laba bersih yang dihasilkan dari setiap rupiah dana yang ditanam dalam total asset. Sebaliknya, semakin rendah hasil pengembalian atas asset berarti semakin rendah pula jumlah laba bersih yang dihasilkan dalam setiap rupiah dana yang tertanam dalam total asset.

Perusahaan yang mengumumkan rugi atau tingkat ROA yang rendah maka akan membawa reaksi negatif dari pasar dan turunnya penilaian atas kinerja perusahaannya dan pada perusahaan yang mengumumkan labanya akan berdampak positif terhadap penilaian pihak lain atas kinerja perusahaannya. Perusahaan yang memiliki ROA yang tinggi dapat dikatakan bahwa laporan keuangan tersebut mengandung berita baik dari 
perusahaan yang mempunyai berita baik akan cendrung menyampaikan laporan keuangannya tepat waktu (Mamduh M. Hanafi, 2014:81).

Astuti (2007:31) mengatakan Perusahaan akan lebih bersedia untuk melaporkan kabar baik (laba) lebih cepat dari pada buruk (rugi) karena efek berita tersebut bisa saja berpengaruh pada harga saham dan lainnya. Dengan demikian, dapat dikatakan bahwa profit merupakan berita baik bagi perusahaan sehingga perusahaan tidak akan menunda penyampaian informasi yang berisi berita baik. Oleh karena itu perusahaan yang mampu menghasilkan profit cenderung lebih tepat waktu dalam penyampaian laporan keuangannya dibandingkan dengan perusahaan yang mengalami kerugian.

\section{Pengaruh CR Terhadap Ketepatan Waktu Pelaporan Keuangan.}

Menurut Kasmir (2011:134) Current Ratio (Rasio Lancar) merupakan rasio untuk mengukur kemampuan perusahaan dalam membayar kewajiban jangka pendek atau utang yang segera jatuh tempo pada saat ditagih secara keseluruhan. Dengan kata lain, seberapa banyak aktiva lancer yang bersedia untuk menutupi kewajiban jangka pendek yang segera jatuh tempo. Rasio lancer dapat dikatakan sebagai bentuk untuk mengukur tingkat keamanan (margin of safety) suatu perusahaan.

Sofyan Syafri Harahap (2008:305) menjelaskan definisi current ratio sebagai berikut: "Rasio-rasio ini menggambarkankemampuan perusahaanmembayar utang jangka pendek. Semakin besar rasio ini semakin baik dan laporan keuangan tersebut mengandung berita baik dari perusahaan yang mempunyai berita baik akan cendrung menyampaikan laporan keuangannya tepat waktu. Rasio ini juga disebut dengan rasio likuiditas".

Hal ini merupakan kabar baik yang harus segera dipublikasikan kepada publik. Oleh karena itu, Semakin likuid perusahaan maka semakin tepat waktu perusahaan dalam menyampaian laporan keuangan. Perusahaan yang mampu membayar hutang jangka pendeknya dianggap sudah baik dalam melakukan kinerja manajemen, sehingga hal ini merupakan kabar baik bagi perusahaan dan segera ingin menunjukan bahwa perusahaan dalam kondisi stabil.

Penelitian (Hilmi \& Ali, 2011) menghasilkan bukti empiris bahwa CR mempengaruhi ketepatan waktu penyampaian laporan keuangan perusahaan. Perusahaan yang yang memiliki tingkat $\mathrm{CR}$ yang tinggi menunjukkan bahwa perusahaan tersebut memiliki kemampuan yang tinggi dalam melunasi kewajiban jangka pendeknya. Hal ini merupakan berita 
baik sehingga perusahaan dengan kondisi seperti ini cenderung tepat waktu dalam menyampaikan laporan keuangannya.

\section{Pengaruh Ukuran Perusahaan Terhadap Ketepatan Waktu Penyampaian Laporan Keuangan}

Salah satu atribut yang dapat dihubungkan dengan ketepatan waktu penyampaian laporan keuangan adalah ukuran perusahaan.Menurut Brigham \& Houston (2010:4) Ukuran perusahaan merupakan ukuran besar kecilnya sebuah perusahaan yang ditunjukan atau dinilai oleh total asset, total penjualan, jumlah laba, beban pajak dan lain-lain. Semakin besar nilai item-item tersebut maka semakin besar pula ukuran perusahaan itu. Perusahaan besar biasanya memiliki asset besar, pendapatan besar, dan perputaran uang yang tinggi sehingga ukuran perusahaan sering dijadikan sebagai proksi, namun umumnya asset digunakan untuk menentukan besarnya ukuran suatu perusahaan karena asset dianggap lebih stabil. Perusahaan besar sering berargumen untuk lebih cepat dalam menyampaikan laporan keuangan karena beberapa alasan. Pertama, perusahaan besar memiliki lebih banyak sumber daya, lebih banyak staf akuntansi dan sistem informasi yang canggih dan memiliki sistem pengendalian intern yang kuat. Kedua, perusahaan besar mendapat pengawasan yang lebih dari investor dan regulator serta lebih menjadi sorotan publik.

Prasetyantoko (2008:257) mengemukakan bahwa: “Aset total menggambarkan ukuran perusahaan, semakin besar aset biasanya perusahaan tersebut semakin besarperusahaan dan lebih konsisten untuk tepat waktu dibandingkan dengan perusahaan kecil dalam menginformasikan laporan keuangannya. Hal ini dikarenakan perusahaan besar cenderung banyak di sorot oleh masyarakat (public eye)"

\section{Kerangka Penelitian}

Penelitian ini menguji pengaruh Opini audit, DER,ROA,dan ukuran perusahaan terhadap ketepatan waktu pelaporan. Pada kerangka pemikiran ini ditunjukan bagaimana pengaruh variabel independen terhadap variabel independen. 
Gambar 2.1 Kerangka Berpikir

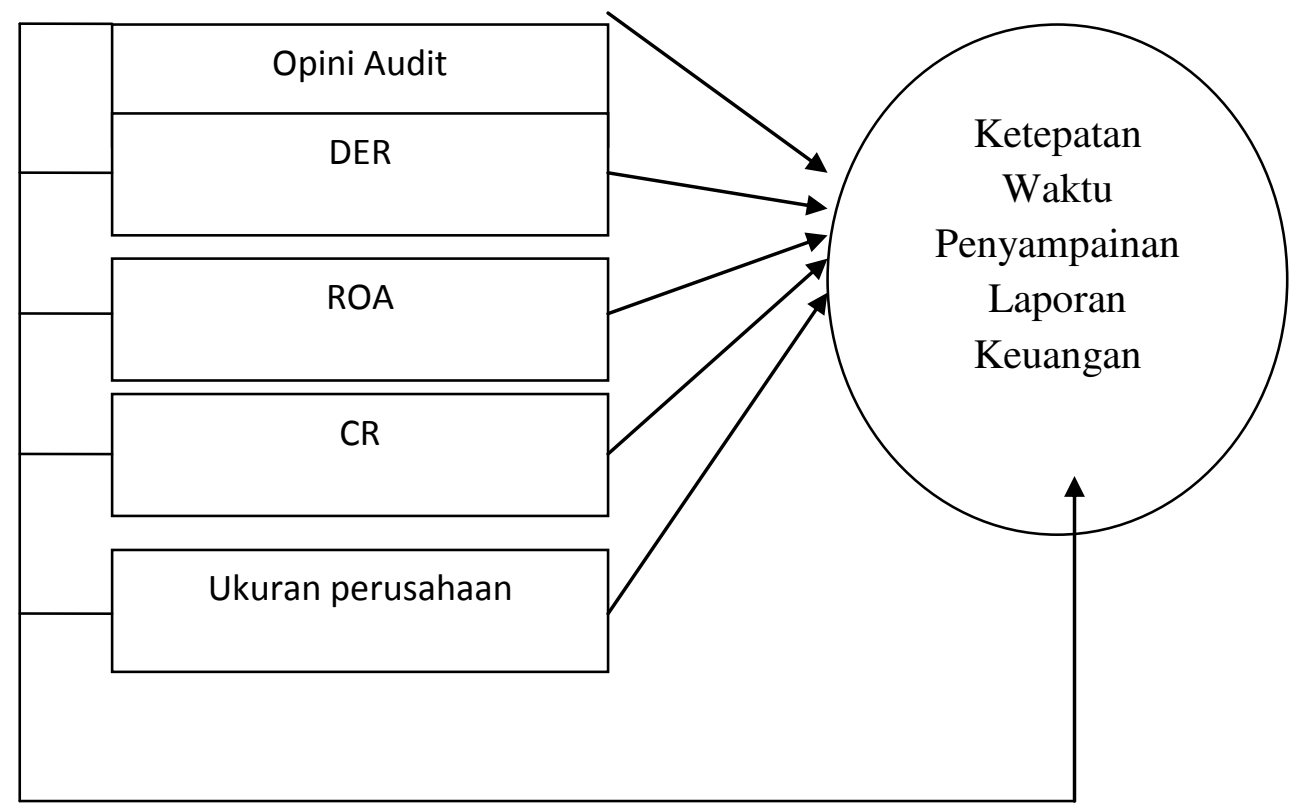

\section{Hipotesis Penelitian}

$\mathrm{H}_{1}$ : Opini auditor berpengaruh positif dan signifikan terhadap ketepatan waktu penyampaian laporan keuanganpada perusahaan Jasa sektor Perdagangan dan Investasi yang terdaftar di bursa efek Indonesia 2016-2017.

$\mathrm{H}_{2}$ :DER berpengaruh negatif dan signifikan terhadap ketepatan waktu penyampaian laporan keuanganpada perusahaan Jasa sektor Perdagangan dan Investasi yang terdaftar di bursa efek Indonesia 2016-2017.

$\mathrm{H}_{3}$ : ROA berpengaruh positif dan signifikan terhadap ketepatan waktu penyampaian laporan keuanganpada perusahaan Jasa sektor Perdagangan dan Investasi yang terdaftar di bursa efek Indonesia 2016-2017.

$\mathrm{H}_{4}$ : CR Perpengaruh positif dan signifikan terhadap ketepatan waktu penyampaian laporan keuangan pada perusahaan manufaktur sektor industri dasar dan kimia yang terdaftar di bursa efek indonesia.

$\mathrm{H}_{5}$ : Ukuran perusahaan dan signifikan berpengaruh positif terhadap ketepatan waktu penyampaian laporan keuanganpada perusahaan 
Jasa sektor Perdagangan dan Investasi yang terdaftar di bursa efek Indonesia 2016-2017.

$\mathrm{H}_{6}$ : Opini auditor, DER, ROA, CR dan Ukuran perusahaanberpengaruh secara signifikan terhadap ketepatan waktu penyampaian laporan keuanganpada perusahaan Jasa sektor Perdagangan dan Investasi yang terdaftar di bursa efek Indonesia 2016-2017.

\section{METODE PENELITIAN}

\section{Populasi dan Sampel}

Populasi yang digunakan adalah perusahaan jasa sektor perdagangan dan investasi yang tercatat di BEI tahun2007-2017 sebanyak 136 perusahaan.

Teknik pengambilan sampel digunakan dalam penelitian menggunakan teknik purposive sampling, yaitu teknik pengambilan sampel dengan menggunakan kriteria (pertimbangan) tertentu.Adapun kriteria penarikan sampel yang digunakan adalah sebagai berikut:

1. Perusahaan Jasa Sektor Perdagangan, dan investasi yang terdaftar di BEI secara berturut-turut pada periode 2016-2017

2. Perusahaan tersebut telah menerbitkan laporan keuangan auditan dan dipublikasikan pada periode 2016-2017.

3. Perusahaan yang menggunakan mata uang Rupiah.

4. Menampilkan data dan informasi yang digunakan untuk menganalisis pengaruh ketepatan waktu penyampaian laporan keuangan untuk periode 2016-2017.

\section{Teknik Analisis Data}

Pengujian hipotesis dilakukan dengan menggunakan regresi logistik karena variabel dependen (Y) diukur dengan variabel dummy dan variabel independen $(\mathrm{X})$ berupa variabel kontinyu maupun variabel kategorial. Dimana dalam penggunaan metode regresi logistic tidak perlu adanya uji asumsi klasik pada variabel bebasnya (Ghozali, 2018:178). Teknik analisis data yang digunakan dalam penelitian ini adalah analisis kuantitatif yaitu pemrosesan dan manipulasi data mentah mengenai informasi yang bermanfaat karena analisis data merupakan suatu proses penyederhanaan data ke dalam bentuk yang mudah di baca dan diinterpretasikan.Model regresi logistik yang digunakan untuk menguji hipotesis penelitian adalah sebagai berikut: 


$$
\ln \frac{T W}{1-T W}=\alpha+\beta 1 X 1+\beta 2 X 2+\beta 3 X 3+\beta 4 X 4+\beta 5 X 5+\varepsilon
$$

Keterangan:

$$
\begin{array}{ll}
\ln \frac{T W}{1-T W}= & \begin{array}{l}
\text { Simbol yang menunjukkan probabiltitas tepat waktu } \\
\text { (kategori } 1 \text { jika tepat waktu, } 0 \text { jika tidak tepat waktu) }
\end{array} \\
\mathrm{TW} & \text { Probabilitas tepat waktu } \\
1-\mathrm{TW}= & \text { Probabilitas tidak tepat waktu } \\
\mathrm{X} 1 & \text { Opini Audit diukur dengan } 1 \text { jika opini wajar tanpa } \\
& \text { pengecualian dan } 0 \text { jika mendapat opini selain wajar } \\
& \text { tanpa pengecualian } \\
= & \text { DER diukur dengan rasio debt equty to ratio } \\
\mathrm{X} 2 & \text { ROA diukur dengan return on assets, } \\
\mathrm{X} 3 & \text { CR diukur dengan current ratio, } \\
\mathrm{X} 4 & \text { Ukuran Perusahaan diukur dengan Total asset(aktiva) } \\
\mathrm{X} 5 & \\
\alpha & \text { konstanta } \\
\varepsilon & \text { kesalahan residual. }
\end{array}
$$

\section{HASIL PENELITIAN DAN PEMBAHASAN}

\section{Statistik Deskriptif}

Statistik deskriptif digunakan untuk menggunakan variabel-variabel dalam penelitian. Penelitian menggunakan statistik deskriptif yang terdiri dari nilai minimum, nilai maksimum, rata-rata (mean), dan standar deviasi (standard deviation) setiap variabel yang di gunakan (Ghozali, 2011:19).

Populasi yang digunakan di dalam penelitian ini adalah Perusahaan yang bergerak dibidang jasa khususnya perusahaan sector Pedagangan dan investasi dengan jumlah 130 perusahaan yang terdaftar di Bursa Efek Indonesia dalam periode 2016-2017. Jumlah sampel yang digunakan dalam penelitian ini berjumlah 74 × 2 tahun dengan total data yang digunakan adalah sejumlah 148 data pengamatan. Berikut ini ditampilkan data statistic secara umum dari keseluruhan data yang digunakan 
Tabel 1 Tabel Deskriptif

\begin{tabular}{|c|c|c|c|c|c|c|c|}
\hline \multicolumn{7}{|l|}{ Descriptive Statistics } \\
\hline & $\mathrm{N}$ & Range & Min & Max & Mean & Std. Dev & Variance \\
\hline $\mathbf{Y}$ & 148 & 1 & 0 & 1 & .035 & .422 & .178 \\
\hline $\mathbf{x 1}$ & 148 & 1 & 0 & 1 & .035 & .426 & .182 \\
\hline $\mathbf{x 2}$ & 148 & 11.2662 & -4.1080 & 7.1582 & .1236915 & 1.5047720 & 2.264 \\
\hline $\mathbf{x} \mathbf{4}$ & 148 & 2.0526 & -1.1952 & .8574 & .0167759 & .2040876 & .042 \\
\hline $\mathbf{x 5}$ & 148 & 42.3419 & .0004 & 42.3423 & .4378293 & 5.3264238 & 28.371 \\
\hline Valid n (listwise) & 148 & 11.2901 & 20.8125 & 32.1026 & .2092367 & 2.5454740 & 6.479 \\
\hline
\end{tabular}

Sumber : data output SPSS 22

Tabel diatas menunjukkan bahwa :

1. Nilai rata-rata ketepatan waktu pelaporan keuangan sebesar 0,77> 0,05 menunjukkan bahwa perusahaan yang menyampaikan laporan keuangan tepat waktu yakni dengan kode 1 lebih banyak muncul dar 148 perusahaan sampel yang diteliti.

2. Variabel Opini Auditor $\left(\mathrm{X}_{1}\right)$ memiliki nilai minimum 0 dan maximum 1 dengan nilai rata-rata 0,76 standar deviasi adalah sebesar 0, .426 jumlah data yang digunakan adalah sebanyak 148

3. Variabel Debt To Equity Ratio $\left(\mathrm{X}_{2}\right)$ memiliki nilai minimum 4.1080 dan maximum dengan nilai rata-rata 1.117525 standar deviasi 1.5047720 adalah sebesar jumlah data yang digunakan adalah sebanyak 148

4. Variabel Return On Asset $\left(\mathrm{X}_{3}\right)$ memiliki nilai minimum -1.1952dan maximum 0.8574 dengan nilai rata-rata 0.021512 standar deviasi adalah sebesar 0.204087 jumlah data yang digunakan adalah sebanyak 148

5. Variabel Current Ratio $\left(\mathrm{X}_{4}\right)$ memiliki nilai minimum 0.0004 dan maximum 42.3423 dengan nilai rata-rata 2.83805 6standar deviasi adalah sebesar 2.838056 jumlah data yang digunakan adalah sebanyak 148

6. Variabel Ukuran Perusahaan $\left(\mathrm{X}_{5}\right)$ memiliki nilai minimum 20.8125 dan maximum 32.1026 dengan nilai rata-rata 25.932009 standar deviasi adalah sebesar 2.5454740 jumlah data yang digunakan adalah sebanyak 148 


\section{Hasil Uji Keseluruhan Model (Overall model Fit)}

Setelah melakukan pengujian deskriptif, langkah selanjutnya adalah melakukan pengujian keseluruhan model. Menurut Gozali (2018:333) untuk menganalisis hasil output data dari regresi logistik dilakukan dengan menggunakan penilaian model fit.

Tabel 2. Hasil Uji Overall Fit Model -2 Log Likelihood Awal

\begin{tabular}{|c|c|c|c|}
\hline \multicolumn{4}{|c|}{ Iteration History ${ }^{\mathrm{a}, \mathrm{b}, \mathrm{c}}$} \\
\hline \multirow{2}{*}{\multicolumn{2}{|c|}{ Iteration }} & \multirow{2}{*}{-2 Log likelihood } & \multirow{2}{*}{$\begin{array}{c}\text { Coefficients } \\
\text { Constant }\end{array}$} \\
\hline & & & \\
\hline \multirow{4}{*}{$\begin{array}{l}\text { Step } \\
0\end{array}$} & 1 & 159.973 & 1.081 \\
\hline & 2 & 159.530 & 1.206 \\
\hline & 3 & 159.529 & 1.210 \\
\hline & 4 & 159.529 & 1.210 \\
\hline
\end{tabular}

Sumber : Hasil Output SPSS

Tabel 3. Hasil Uji Overall Fit Model -2 Log Likelihood Akhir

\begin{tabular}{|c|c|c|c|c|c|c|c|c|}
\hline \multicolumn{9}{|c|}{ Iteration History $^{\mathrm{a}, \mathrm{b}, \mathrm{c}, \mathrm{d}}$} \\
\hline \multirow{2}{*}{\multicolumn{2}{|c|}{$\begin{array}{l}\text { Iteratio } \\
\mathrm{n}\end{array}$}} & \multirow{3}{*}{$\begin{array}{c}\begin{array}{c}-2 \log \\
\text { likelihoo } \\
\mathrm{d}\end{array} \\
109.844\end{array}$} & \multicolumn{6}{|c|}{ Coefficients } \\
\hline & & & Constant & $\mathrm{x} 1(1)$ & $\mathrm{x} 2$ & $\mathrm{x} 3$ & $\mathrm{x} 4$ & $\mathrm{x} 5$ \\
\hline \multirow{6}{*}{$\begin{array}{l}\text { St } \\
\text { ep } \\
1\end{array}$} & 1 & & -2.952 & 2.094 & -.127 & .979 & -.061 & .105 \\
\hline & 2 & 100.295 & -5.427 & 2.804 & -.230 & 1.693 & -.091 & .205 \\
\hline & 3 & 99.087 & -7.061 & 3.169 & -.285 & 2.042 & -.103 & .270 \\
\hline & 4 & 99.048 & -7.456 & 3.253 & -.297 & 2.114 & -.106 & .285 \\
\hline & 5 & 99.048 & -7.472 & 3.256 & -.297 & 2.116 & -.106 & .285 \\
\hline & 6 & 99.048 & -7.472 & 3.256 & -.297 & 2.116 & -.106 & .285 \\
\hline
\end{tabular}

Sumber : Hasil Output SPSS 22

Berdasarkan tabel 2 dan tabel 3, diperoleh informasi bahwa pengujian dilakukan dengan membandingkan nilai antara -2 Log Likehood (-2LL) awal (Block Number $=0$ ) dengan nilai -2 Log Likehood $(-2 L L)$ akhir (Block Number=1). Nilai -2LL awal adalah 159.529 .Setelah dimasukkan kelima variabel independen, maka nilai -2LL akhir mengalami penurunan menjadi 99.048 . Penurunan -2 Log Likehood ini menunjukkan model regresi yang lebih baik atau dengan kata lain model yang dihipotesiskan fit dengan data

\section{a. Hasil Uji Kelayakan Model Regresi}

Ghozali (2018:233) Kelayakan model regresi dinilai dengan menggunakan Hosmer and Lemeshow's Goodness of Fit Test. Hosmer and 
Lemeshow's Goodness of Fit Test menguji hipotesis nol bahwa data empiris cocok atau sesuai dengan model (tidak ada perbedaan antara model dengan data sehingga model dapat dikatakan fit.Jika nilai statistik Hosmer and Lemeshow's Goodness of Fit Test sama dengan atau kurang dari 0,05, maka hipotesis nol ditolak yang berarti ada perbedaan signifikan antara model dengan nilai observasinya sehingga Goodness of Fit model tidak baik karena model tidak dapat memprediksi nilai observasiny.

Tabel 4. Hasil Uji Hosmer And Lemeshow Test And Lemeshow's Goodness of Fit Test

\begin{tabular}{|l|r|r|rr|}
\hline \multicolumn{5}{|c|}{ Hosmer and Lemeshow Test } \\
\hline $\begin{array}{l}\text { Ste } \\
\mathrm{p}\end{array}$ & Chi-square & Df & \multicolumn{2}{|c|}{ Sig. } \\
\hline 1 & & & & \\
\hline
\end{tabular}

Sumber : Hasil Output SPSS 22

Dari tampilan tabel 4 Hosmer and Lemesshow's di atas terlihat bahwa besarnya nilai statistik Hosmer and Lemesshow's Goodness of Fit test sebesar 4,379 dengan probabilitas signifikansi 0,821 di mana 0,821>0,05. Hal ini berarti model regresi yang dipergunakan dalam penelitian ini layak dipakai untuk analisis selanjutnya, karena tidak ada perbedaan yang nyata antara klasifikasi yang diprediksi dan klasifikasi yang diamati.

\section{b. Hasil Uji Koefisien Determinasi (Negelkerke R. Square)}

Ghozali (2018: 233) Mengatakan Besarnya nilai koefisien determinasi pada model regresi logistik ditunjukkan dengan nilai Nagelkerke $R$ square. Nilai Nagelkerke $R$ square menunjukkan variabilitas variabel dependen yang dapat dijelaskan oleh variabilitas variabel independen, sedangkan sisanya dijelaskan oleh variabel-variabel lain di luar model penelitian.

Tabel 5. Hasil Uji koefisien Determinasi

\begin{tabular}{|l|c|c|r|}
\hline \multicolumn{4}{|c|}{ Model Summary } \\
\hline $\begin{array}{l}\text { Ste } \\
\mathrm{p}\end{array}$ & $\begin{array}{c}-2 \text { Log } \\
\text { likelihood }\end{array}$ & Cox \& Snell R Square & Nagelkerke R Square \\
\hline 1 & $99.048^{\mathrm{a}}$ & .335 & .509 \\
\hline \multicolumn{4}{|l|}{ Sumber : Hasil Output SPSS 22 } \\
\hline
\end{tabular}


Tabel 5 menunjukkan bahwa nilai Nagelkerke R. Square sebesar 0, .509. Hal ini menunjukkan bahwa variable independen ( Opini auditor, DER, ROA, CR dan Ukuran Perusahaan) dapat menjelaskan Variabel Dependen (Ketepatan waktu Pelaporan) sebesar $51 \%$ sedangkan $49 \%$ dipengaruhi oleh faktor-faktor lain yang tidak diteliti.

\section{c. Tabel Klasifikasi}

Menurut Gozali (2018: 335) tabel kalsifikasi menunjukkan kekuatan prediksi dari model regresi untuk memprediksi probabilitas dalam ketepatan Penyampain laporan keuangan perusahaan.Kekuatan prediksi dari model regresi untuk memprediksi kemungkinan terjadinya variabel terikat dinyatakan dalam persen. Pada kolom merupakan dua nilai prediksi dari variabel dependen dan hal ini Tepat waktu 1 dan Tidak Tepat waktu 0 , sedangkan pada baris menunjukkan nilai observasi sesungguhnya dari variabel depanden dan hal ini Tepat Waktu 1 dan Tidak Tepat waktu 0. Hasil tabel klasifikasi ditampilkan dalam tabel dibawah ini:

Tabel 6. Tabel Klasifikasi

\begin{tabular}{|c|c|c|c|c|c|}
\hline \multicolumn{6}{|c|}{ Classification Table $^{\mathbf{a}, \mathrm{b}}$} \\
\hline & \multirow{3}{*}{\multicolumn{2}{|c|}{ Observed }} & \multicolumn{3}{|c|}{ Predicted } \\
\hline & & & \multicolumn{2}{|c|}{ 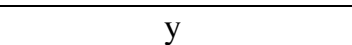 } & \multirow{2}{*}{$\begin{array}{c}\text { Percentage } \\
\text { Correct }\end{array}$} \\
\hline & & & $\begin{array}{l}\text { Tidak tepat } \\
\text { waktu }\end{array}$ & $\begin{array}{l}\text { Tepat } \\
\text { waktu }\end{array}$ & \\
\hline \multirow[t]{3}{*}{ Step 0} & \multirow[t]{2}{*}{$\mathrm{y}$} & $\begin{array}{l}\text { Tidak tepat } \\
\text { waktu }\end{array}$ & 0 & 34 & .0 \\
\hline & & Tepat waktu & 0 & 114 & 100.0 \\
\hline & \multicolumn{2}{|c|}{ Overall Percentage } & & & 77.0 \\
\hline
\end{tabular}

\begin{tabular}{|c|c|c|c|c|c|}
\hline \multicolumn{6}{|c|}{ Classification Table $^{\mathrm{a}}$} \\
\hline & \multirow{3}{*}{\multicolumn{2}{|c|}{ Observed }} & \multicolumn{3}{|c|}{ Predicted } \\
\hline & & & \multicolumn{2}{|l|}{$\mathrm{Y}$} & \multirow{2}{*}{$\begin{array}{c}\text { Percentage } \\
\text { Correct }\end{array}$} \\
\hline & & & $\begin{array}{l}\text { Tidak tepat } \\
\text { waktu }\end{array}$ & $\begin{array}{l}\text { Tepat } \\
\text { waktu }\end{array}$ & \\
\hline \multirow[t]{3}{*}{ Step 1} & \multirow[t]{2}{*}{$\mathrm{Y}$} & $\begin{array}{l}\text { Tidak tepat } \\
\text { waktu }\end{array}$ & 21 & 13 & 61.8 \\
\hline & & Tepat waktu & 6 & 108 & 94.7 \\
\hline & \multicolumn{2}{|c|}{ Overall Percentage } & & & 87.2 \\
\hline
\end{tabular}


Tampilan dalam tabel tersebut menunjukkan kekuatan prediksi dari model regresi untuk memprediksi kemungkinan menyampaikan laporan keuangannya tepat waktu adalah sebesar 94,7\% (108/114). Hal ini menunjukkan bahwa dengan menggunakan model regresi tersebut, terdapat 108 perusahaan menyampaikan laporan keuangannya tepat waktu dari 144 perusahaan dapat juga dilihat bahwa menurut prediksi, perusahaan yang menyampaikan laporan keuangannya tidak tepat waktu sebanyak 21 perusahaan, sedangkan observasi sesungguhnya menunjukkan bahwa perusahaan yang menyampaikan laporan keuangannya tidak tepat waktu adalah 34 perusahaan jadi kecepatan model ini adalah 61,8\% (21/34) atau secara keseluruhan ketepatan klasifikasi adalah 87,2\% $(108+21) / 148$.

\section{d. Hasil Uji Hipotesis}

Berdasarkan hasil perhitungan dengan menggunakan program SPSS ringkasan hasil pengujian dapat di lihat pada tabel berikut :

Tabel 7. Hasil Uji Regresi Logistik

\begin{tabular}{|l|l|r|r|r|r|r|r|}
\hline \multicolumn{2}{|c|}{ Variables in the Equation } \\
\hline \multirow{3}{*}{$\begin{array}{l}\text { Step } \\
1\end{array}$} & $\mathrm{x} 1(1)$ & 3.256 & .586 & 30.892 & 1 & .000 & 25.951 \\
\cline { 2 - 9 } & $\mathrm{x} 2$ & -.297 & .162 & 3.350 & 1 & .067 & .743 \\
\cline { 2 - 8 } & $\mathrm{x} 3$ & 2.116 & 1.184 & 3.195 & 1 & .074 & 8.302 \\
\cline { 2 - 8 } & $\mathrm{x} 4$ & -.106 & .050 & 4.529 & 1 & .033 & .900 \\
\cline { 2 - 8 } & $\mathrm{x} 5$ & .285 & .118 & 5.822 & 1 & .016 & 1.330 \\
\cline { 2 - 8 } & Constant & -3.121 & 5.731 & 1 & .017 & .001 \\
\hline
\end{tabular}

Sumber : Hasil Output SPSS 22

\section{e. Hasil Uji Regresi Logistik Secara Simultan}

Pengujian regresi logistik secara simultan pada penelitian ini dapat dilihat berdasarkan tabel Omnibus Tests of Model Coefficients.Tujuannya adalah untuk melihat pengaruh variabel bebas (intensitas aset tetap, leverage, likuiditas pertumbuhan perusahaan dan ukuran perusahaan,) secara bersama terhadap variabel terikat (revaluasi). Hasil pengujiannya adalah sebagai berikut: 
Tabel 8. Pengujian Regresi Logistik Secara Simultan

\begin{tabular}{|l|l|r|r|r|}
\hline \multicolumn{7}{|c|}{ Omnibus Tests of Model Coefficients } \\
\hline \multirow{2}{*}{$\begin{array}{l}\text { Step } \\
1\end{array}$} & Step & Chi-square & df & Sig. \\
\cline { 2 - 6 } & Block & 60.481 & 5 & .000 \\
\cline { 2 - 6 } & Model & 60.481 & 5 & .000 \\
\hline
\end{tabular}

Sumber : Hasil Output SPSS 22

Berdasarkan tabel 8 data secara simultan menunjukkan hasil signifikansi 0,000 lebih kecil dari $\alpha=0,05$. Hal ini berarti bahwa semua variabel independen berpengaruh secara bersama-sama terhadap Ketepatan Waktu Penyampain Laporan keuangan. Hasil tersebut menjelaskan bahwa semua variabel independen jika diuji secara bersamaan dalam penelitian ini berpengaruh secara signifikan terhadapKetepatan Waktu Penyampain Diperusahaan jasa sektor perdagangan dan investasi yang terdaftar di BEI 2016-.2017.

\section{Pembahasan Hasil Penelitian}

Penelitian ini merupakan studi mengenai faktor-faktor yang mempengaruhi Ketepatan Penyampaian laporan keuangan. Penelitian terhadap 136 perusahaan dengan jumlah unit analisis sebanyak 148 (sesuai dengan 2 periode penelitian) yang dipilih berdasarkan metode purposive sampling selama tahun 2016-2017 .Berikut ini pembahasan atas hasil pengujian yang telah dilakukan.

\section{a. Pengaruh Opini Auditor Terhadap Ketepatan waktu penyampaian Penyampaian Laporan Keuangan}

Pengujian hipotesis 1 dalam penelitian ini bertujuan untuk menguji pengaruh variabel Opini Auditor terhadap ketepatan waktu penyampain laporan keungan. Opini Auditor diukur dengan menghitung Variabel dummy yakni 1 wajar tanpa pengecualian dan 0 selain wajar tanpa pengecualian.Hasil uji hipotesis yang mana nilai Opini Auditor memiliki nilai Positif dengan koefisien 3.256 artinya terjadi hubungan positif antara Opini auditor dengan Ketepatan waktu penyampaian laporan keuangan dimana perusahaan yanga mendapatkan Opini auditor wajar tanpa pengecualian menyampaikan laporan keuangannya tepat waktu dan 
tingkat signifikansi pada 0,00 yang lebih kecil dibandingkan taraf signifikansi 5\% (0,05).

Berdasarkan hasil uji menunjukkan bahwa Opini auditor berpengaruh positif signifikan terhadapKetepatan waktu penyampaian laporan keuanganartinya jika variabel independen lain nilainya tetap danOpini auditor mengalami kenaikan 1\%, maka Ketepatan waktu penyampaian laporan keuangan (Y) mengalami Kenaikan sebesar 25.951. Hasil uji penelitian ini Searah dengan teori Agoes Sukirsno (2013:31) yang mengatakan Opini Setiap perusahaan tentunya ingin mendapatkan unqualified opinion atas laporan keuangannya karena opini ini merupakan good news perusahaan. Sedangkan qualified opinion adalah opini yang sebisa mungkin dihindari perusahaan, karena hal ini merupakan bad news perusahaan. Perusahaan yang mendapat unqualified opinion cenderung lebih cepat menyampaikan laporan keuangannya daripada perusahaan yang menerima qualified opini.

Hasil penelitian ini bertolak belakang dengan hasil penelitian sebelumnya seperti penelitian yang dilakukan oleh Hartono (2015) yang hasil penelitiannya menunjukan bahwa opini auditor tidak berpengaruh secara signifikan terhadap ketepatan waktu penyampaian laporan keuanganNamun Penelitian ini mendukung penelitian R. Ait Putri Novianti dan Nadia Putri Sari (2015) yang mengatakan bahwa Opini Auditor berpengaruh terhadap ketepatan waktu penyampaian laporan keuangan.

\section{b. Pengaruh DER Terhadap Ketepatan Waktu Penyampain Laporan keuangan}

Pengujian hipotesis 2 dalam penelitian ini bertujuan untuk menguji pengaruh variabel terhadap ketepatan waktu penyampain laporan keungan. $D E R$ diukur membandingkan antara seluruh hutang, termasuk hutang lancar dengan seluruh ekuitas.Hasil uji hipotesis yang mana nilai $D E R$ memiliki nilai Negatif dengan koefisien -0.297artinya terjadi hubungan Negatif antara $D E R$ dengan Ketepatan waktu penyampaian laporan keuangan dimana semakin Rendah $D E R$ maka menyampaikan laporan keuangannya tepat waktu dan tingkat signifikansi pada 0,067 yang lebih besar dibandingkan taraf signifikansi 5\% $(0,05)$.

Berdasarkan hasil uji menunjukkan bahwaDERberpengaruh Negatiftidak signifikan terhadapKetepatan waktu penyampaian laporan keuangan artinya jika variabel independen lain nilainya tetap dan $D E R$ 
mengalami Penurunan 1\%, maka Ketepatan waktu penyampaian laporan keuangan (Y) mengalami Kenaikan Sebesar 0.743. Hasil uji penelitian ini Searah dengan teoriSofyan Syafri Harahap (2008:303) menjelaskan definisi debt to equity sebagai berikut: "Rasio-rasio ini menggambarkan sampai sejauh mana modal pemilik dapat menutupi utang-utang kepada pihak luar. Semakin kecil rasio ini semakin baik dan laporan keuangan tersebut mengandung berita baik dari perusahaan yang mempunyai berita baik akan cendrung menyampaikan laporan keuangannya tepat waktu. Rasio ini juga disebut dengan rasio leverage"

Penelitian ini mendukung hasil penelitianUpik Maharani Darsono (2015) yang mengatakan bahwa DER berpengaruh negatif dan tidak signifikan terhadap ketepatan waktu penyampaian laporan keuangan dan Bertolak belakang denganpenelitian I G A P Bunga Valentina dan Gayatri(2018) yang mengatakan DER berpengaruh positif dan signifikan terhadap Ketepatan Waktu penyampain laporan keuangan.

\section{c. Pengaruh ROA Terhadap Ketepatan Waktu Penyampaian Laporan Keuangan}

Pengujian hipotesis 3 dalam penelitian ini bertujuan untuk menguji pengaruh variabel terhadap ketepatan waktu penyampain laporan keuangan. ROA diukur membandingkan antara Jumlha Laba Bersih dengan seluruh Jumlah ekuitas.Hal ini dapat dilihat dari hasil uji hipotesis yang mana nilai $R O A$ memiliki nilai Positif dengan koefisien 2.116 artinya terjadi hubungan Positif antara $R O A$ dengan Ketepatan waktu penyampaian laporan keuangan dimana Apabila $R O A$ mengalami kenaikan maka menyampaikan laporan keuangannya tepat waktu dan dengan tingkat signifikansi pada 0.074 yang lebih besar dibandingkan taraf signifikansi $5 \%(0,05)$.

Berdasarkan hasil uji menunjukkan bahwa $R O A$ berpengaruh Positif tidak signifikan terhadapKetepatan waktu penyampaian laporan keuanganartinya jika variabel independen lain nilainya tetap danROAmengalami Kenaikan 1\%, maka Ketepatan waktu penyampaian laporan keuangan (Y) mengalami Kenaikan Sebesar 8.302. Hasil uji penelitian ini Searah teori yang ,menyatakan Perusahaan yang mengumumkan rugi atau tingkat ROA yang rendah maka akan membawa reaksi negatif dari pasar dan turunnya penilaian atas kinerja perusahaannya dan pada perusahaan yang mengumumkan labanya akan berdampak positif terhadap penilaian pihak lain atas kinerja perusahaannya. Perusahaan yang 
memiliki ROA yang tinggi dapat dikatakan bahwa laporan keuangan tersebut mengandung berita baik dari perusahaan yang mempunyai berita baik akan cendrung menyampaikan laporan keuangannya tepat waktu (Mamduh M. Hanafi, 2014:81).

Hasil penelitian ini tidak sejalan dengan penelitian Paransa , Azhari dan Aldilla mengatakan bahwa ROA berpengaruh signifkan terhadap Ketepatan waktu penyampaian. Sedangkan sejalan dengan penelitian ulfa nafilah anggreni (2018) mengatakn bahwa roa tidak berpengaruh terhadap ketepatan waktu

\section{d. Pengaruh CR Terhadap Ketepatan Waktu Penyampaian Laporan Keuangan}

Pengujian hipotesis 4 dalam penelitian ini bertujuan untuk menguji pengaruh variable terhadap ketepatan waktu penyampain laporan keuangan. $C R$ diukur membandingkan antara Jumlah Utang lancer dengan Jumlah Aktiva Lancar.Hal ini dapat dilihat dari hasil uji hipotesis yang mana nilai $C R$ memiliki nilai Negatif dengan koefisien-0.106 artinya terjadi hubungan Negatif antara $C R$ dengan Ketepatan waktu penyampaian laporan keuangan dimana Apabila $C R$ mengalami Penurunan maka menyampaikan laporan keuangannya tepat waktu dan dengan tingkat signifikansi pada 0.033 yang lebih Kecil dibandingkan taraf signifikansi $5 \%(0,05)$.

Berdasarkan hasil uji menunjukkan bahwa $C R$ berpengaruh Negatif signifikan terhadap Ketepatan waktu penyampaian laporan keuangan artinya jika variabel independen lain nilainya tetap dan $C R$ mengalami Penurunan $1 \%$, maka Ketepatan waktu penyampaian laporan keuangan (Y) mengalami Kenaikan Sebesar 0.900. Hasil uji penelitian tidak searah dengan teori , Sofyan Syafri Harahap (2008:305) menjelaskan definisi current ratio sebagai berikut: "Rasio-rasio ini menggambarkankemampuan perusahaan membayar utang jangka pendek. Semakin besar rasio ini semakin baik dan laporan keuangan tersebut mengandung berita baik dari perusahaan yang mempunyai berita baik akan cendrung menyampaikan laporan keuangannya tepat waktu. Rasio ini juga disebut dengan rasio likuiditas".

Penelitian ini mendukung penelitian Sigit Mareta (2015) yang mengatakan bahwa likuiditas (CR) tidak berpengaruh positif terhadap ketepatan waktu Sedangkan penelitian ini bertolak belakang hasil penelitian Rizki Pratama Johanis Paransa ,Muhammad Azhar dan Aldilla 
Iradianty(2016)mengatakan bahwa CR berpengaruh secara positif terhadap ketepatan waktu.

\section{e. Pengaruh Ukuran Perusahaan Ketepatan Waktu Penyampaian Laporan Keuangan}

Pengujian hipotesis 5 dalam penelitian ini bertujuan untuk menguji pengaruh variabel Ukuran perusahaan terhadap ketepatan waktu penyampain laporan keaungan.Ukuran aktiva digunakan untuk mengukur besarnya perusahaan, ukuran aktiva tersebut diukur sebagai logaritma dari total aktiva"..Hasil uji hipotesis yang mana nilai Ukuran perusahaan memiliki nilai Positif dengan koefisien 0.285artinya terjadi hubungan positif antara Ukuran perusahaan dengan Ketepatan waktu penyampaian laporan keuangan dimana Ukuran perusahaan naik makan menyampaikan laporan keuangannya tepat waktu dan tingkat signifikansi pada 0.016yang lebih kecil dibandingkan taraf signifikansi 5\% $(0,05)$.

Berdasarkan hasil uji menunjukkan bahwa Ukuran perusahaan berpengaruh positif signifikan terhadap Ketepatan waktu penyampaian laporan keuangan artinya jika variabel independen lain nilainya tetap dan Ukuran perusahaan mengalami kenaikan 1\%, maka Ketepatan waktu penyampaian laporan keuangan (Y) mengalami Kenaikan sebesar1.330. Hasil uji penelitian ini Searah dengan teoriPrasetyantoko (2008:257) mengemukakan bahwa: "Aset total menggambarkan ukuran perusahaan, semakin besar aset biasanya perusahaan tersebut semakin besarperusahaan dan lebih konsisten untuk tepat waktu dibandingkan dengan perusahaan kecil dalam menginformasikan laporan keuangannya. Hal ini dikarenakan perusahaan besar cenderung banyak di sorot oleh masyarakat (public eye)"

Hasil penelitian ini sejalan dan mendukung hasil penelitian dari R. A Novianti dan Nadia yang mengatakan bahwa Ukuran perusahaan berpengaruh secara signifikan terhadap ketepatan waktu penyampaian laporan keuangan dan bertolak belakang dengan penelitian hartono (2015) yang menyatakan bahwa ukuran perusahaan tidak berpengaruh signifikan terhadap ketepatan waktu penyampaian laporan keuangan.

\section{KESIMPULAN DAN SARAN}

\section{Kesimpulan}

Berdasarkan pengujian dan pembahasan yang telah dijelaskan pada bagian sebelumnya, dapat diambil kesimpulan bahwa :

1. Opini Auditor dan. Ukuran Perusahaan berpengaruh positif dan signifikan terhadap ketepatan waktu pelaporan keuangan diperusahaan 
Jasa Sektor Perdagangan dan investasi yang terdaftar di BEI periode 2016-2017.

2. DER berpengaruh Negatif dan tidak signifikan terhadap ketepatan waktu pelaporan keuangan diperusahaan Jasa Sektor Perdagangan dan investasi yang terdaftar di BEI periode 2016-2017.

3. ROA berpengaruh positif dan tidak signifikan terhadap ketepatan waktu pelaporan keuangan diperusahaan Jasa Sektor Perdagangan dan investasi yang terdaftar di BEI periode 2016-2017..

4.Current Ratio berpengaruh Negatif dan signifikan terhadap ketepatan waktu pelaporan keuangan diperusahaan Jasa Sektor Perdagangan dan investasi yang terdaftar di BEI periode 2016-2017.

5.Opini Auditor, DER ,ROA, CR dan Ukuran Perusahaan berpengaruh Secara signifikan terhadap Ketepatan Waktu Penyampain Laporan keuangan pada perusahaan sektor perdagangan dan investasi yang terdaftar di BEI 2016-.2017.

\section{Saran} berikut:

Berdasarkan temuan penelitian ini, maka disampaikan saran sebagai

1. Penelitian selanjutnya dapat menambahkan dan mengantikan variable lain yang berhubungan dengan ketepatan waktu penyampaian laporan keuangan.

2. Menambah jumlah tahun pengamatan dengan lebih dari 2 tahun.

\section{DAFTAR PUSTAKA}

Anggraini, Nafilah Ulfa. 2018. "faktor faktor yang mempengaruhi ketepatan waktu pelaporan keuangan pada perusahaan Tambang yang tereindeks di ISSI tahun 2016-2017'.Skripsi. Institut Agama Islam Surakarta

Astuti. 2007. Pedoman Praktis Memahami Laporan Keuangan (Tips bagi Investor, Direksi, dan Pemegang Saham), Penerbit Andi, Yogyakarta.

Eugene F Brigham,Joel F Houston. 2011. Manajemen KeuanganEdisi 11 Buku 2. Jakarta: Penerbit Erlangga

Eugene F Brigham,Joel F Houston. 2011. Dasar - dasar Managemen Keuangan. Jakarta: Salemba Empat.

Gozali, Imam. 2011. Aplikasi Analisis Multivariate dengan Program SPSS. Semarang: Badan Penerbit Universitas Diponegoro.

Hartono, 2015. Likuiditas, opini audit, ukuran perusahaan dan profitabilitas pada perusahaan manufaktur yang terdaftar di Bursa Efek Indonesia. E-Jurnal. Universitas Prima Indonesia-Medan 
Harahap, Sofyan Syafri. 2012. Analisis Krisis atas Laporan Keuangan. Jakarta: PT Raja Grafindo Persada.

Herry 2012. Analsis Laporan Keuangan . Jakarta: Grasindo

IKATAN AKUNTAN INDONESIA(IAI), 2018. Standar Akuntansi Keuangan.Jakarta : Selemba Empat

Kasmir, 2011. Analisis Laporan Keuangan. Jakarta: PT raja Grafindo Persada

Darsono, Upik Maharani,2015. Faktor - faktor yang mempengaruhi ketepatan penyampaian laporan. E-JurnalAkuntansi Fakultas Ekonomika dan Bisnis Universitas Diponegoro-Semarang

Hanafi, Mamduh M. 2014. Analisis Laporan Keuangan: Cetakan ketiga, UPP STIM YKPN, Yogyakarta.

Muliyadi,2014. Auditing, Jakarta : Selemba Empat

Novatiani R. Ait dan Nadia Putri A. 2016. Pengaruh Leverage, Ukuran Perusahaan, Opini Auditor, dan Kompleksitas Operasi Perusahaan terhadap ketepatan waktu penyampaian laporan keuangan perusahaan. E-Jurnal. Universitas Widytama-Bandung.

Paransa, Rizki Pratama Johanis Paransa ., Azhari, Muhammad dan Azhari Aldilla Iradianty. 2016 "Analisis pengaruh profitabiltas, likuiditas, leverage, ukuran perusahaan terhadap ketepatan pelaporan laporan keuangan diperusahaan yangterdaftar diBEI pada sektor pertambangan". E-Jurna Fakultas Ekonomi dan Bisnis, Universitas Telkom-Bandung

Prasetyantoko.2008.Dasar manajemenJakarta : PT. Gramedia Pustaka Utama.

Peraturan Otoritas Jasa Keuangan, 2016. Tentang Laporan Tahunan Emiten atau Perusahaan Publik, Jakarta

Mareta,Sigit. 2016 . "Analisis faktor-faktor yang mempengaruhiI timelines publikasi laporan keuangan".E-JurnalFakultas Ekonomi dan Bisnis Universitas Mercu Buana-Jakarta

Sukrisno,Agoes.2013.Auditing: (Pemeriksaan Akuntan) oleh Kantor Akuntan Publik Jilid I. Jakarta: Lembaga Penerbit Fakultas Ekonomi Universitas Indonesia

Silalahi, Desi uli. 2016. "Pengaruh DER,ROA dan Ukuran perusahaan terhadap ketepatan waktu penyampain laporan keuangan perusahan Real estate dan Property". Skripsi. Universitas Katolik Santo Thomas-Medan

Sugiyono, Metode Penelitian Pendidikan. Bandung: PT.Alfabeta

Valentina, I gap dan Gayatri , 2018." Pengaruh Profitabilitas, Ukuran Perusahaan, Struktur Kepemilikan, Leverage, Dan Umur Perusahaan Pada Ketepatan Waktu Pelaporan Keuangan”. E-Jurnal Akuntansi Universitas UdayanaBali

www.idx.com

www.ok saham.com 